Historic, archived document

Do not assume content reflects current scientific knowledge, policies, or practices. 

$84 B$

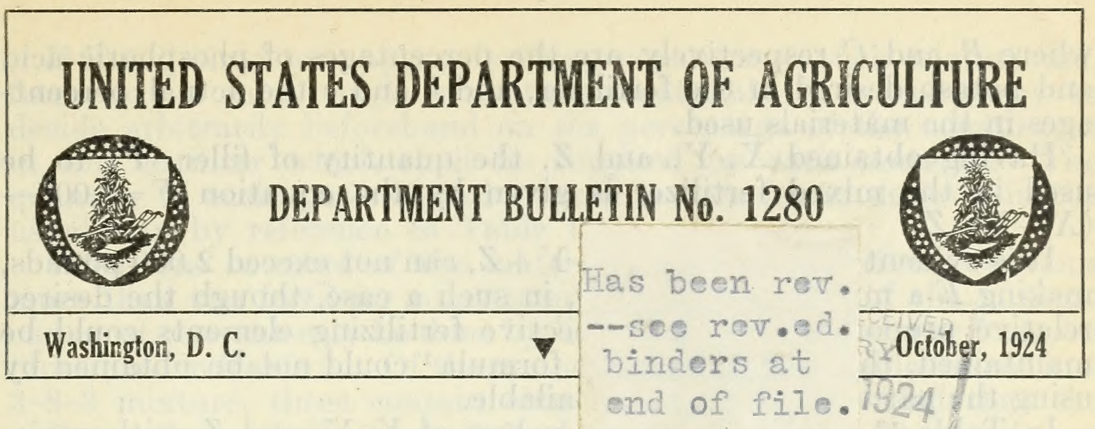

\section{THE COMPUTATION OF FERTILIZER MIXTURES FROM CONCENTRATED MATERIALS}

By Albert R. Mer7, Associate Chemist, and Wilmiam H. Ross, Chemist, Bureau of Soils

\section{CONTENTS}

The triangular system for fertilizer mixtures.

Factors that influence the concentration of fertilizers

Concentrated fertilizer compounds

Standard fertilizer mixtures for concentrated materials.

Page

\section{INTRODUCTION}

The principal inorganic materials now used in the manufacture of fertilizers are acid phosphate, sodium nitrate, ammonium sulphate and various potash salts. All of these materials, which amount to 70 per cent of the total consumed in the fertilizer industry in this country, have the feature in common that they contain but one fertilizing element. A number of organic materials such as cottonsecd meal, tankage, and fish scrap contain marketable quantities of two, or even all three, of the essential constituents of fertilizers; but it of ten happens that the value of one of the constituents so much exceeds that of the others that the latter are frequently disregarded. The calculation of the materials required in the manufacture of the great bulk of mixed fertilizers is therefore a comparatively simple matter.

Thus, for example, the quantity of a material, such as ammonium sulphate with 25 per cent ammonia, required in a ton (2,000 pounds) of a fertilizer mixture to contain, say, 8 per cent of ammonia is simply obtained by multiplying the latter percentage by 2,000 and dividing by the former percentage $(2,000 \times 8 / 25=640)$. Or, in general, if $a$ is the per cent of ammonia in the material, and $A$ the desired percentage of ammonia in the complete fertilizer, then $X$ (the quantity of material required) is given by the equation $X=\frac{2,000 \mathrm{~A}}{a}$.

In the same way, the quantities $Y$ and $Z$ of the phosphoric acid and potash materials required in a complete fertilizer are given by the equations:

$$
Y=2,000 \frac{B}{b} \quad \text { and } \quad Z=2,000 \frac{C}{c}
$$


where $B$ and $C$ respectively are the percentages of phosphoric acid and potash desired in the fertilizer, and $b$ and $c$ the actual percentages in the materials used.

Having obtained $X, Y$, and $Z$, the quantity of filler $(F)$ to be used in the mixed fertilizer is given by the equation $F=2,000-$ $(X+Y+Z)$.

It is evident that the sum, $X+Y+Z$, can not exceed 2,000 pounds, making $F$ a minus quantity; for, in such a case, though the desired relative proportions of the respective fertilizing elements could be maintained, the desired analysis formula ${ }^{1}$ could not be obtained by using the particular materials available.

In Table $1^{2}$ are given directly values of $X, Y$, and $Z$, with variations of $A, B$, or $C$, from one-half to 20 per cent; and of $a, b$, or $c$, from 1 to 50 per cent. Thus, to find the amount of a material (containing any particular per cent of fertilizer constituent given in the first column of figures) required for 2,000 pounds of fertilizer (containing a desired per cent of the same constituent given in the top line of figures), use the number of pounds of this material shown where the horizontal and vertical lines from the two pereentages cross.

TABLE 1.-Weights of single fertilizer constituent materials required for fertilizer formulae

\begin{tabular}{|c|c|c|c|c|c|c|c|c|c|c|c|c|c|c|c|c|c|c|c|c|c|}
\hline \multirow{2}{*}{$\begin{array}{l}\text { Per cent } \\
\text { in } \\
\text { material }\end{array}$} & \multicolumn{21}{|c|}{ Per cent desired } \\
\hline & $1 / 2$ & 1 & 2 & 3 & 4 & 5 & 6 & 7 & 8 & 9 & 10 & 11 & 12 & 13 & 14 & 15 & 16 & 17 & 18 & 19 & 20 \\
\hline & 1000 & 2000 & & & & & & & & & & & & & & & & & & & \\
\hline & $\begin{array}{r}500 \\
-333\end{array}$ & $\begin{array}{r}1000 \\
667\end{array}$ & $\begin{array}{l}2000 \\
1333\end{array}$ & 2000 & & & & & & & & & & & & & & & & & \\
\hline & 250 & 500 & 1000 & 1500 & 2000 & & & & & & & & & & & & & & & & \\
\hline ?- & 200 & 400 & 800 & 1200 & 1600 & 2000 & & & & & & & & & & & & & & & \\
\hline 6. & 167 & 333 & 667 & 1000 & 1333 & 1667 & 2000 & & & & & & & & & & & & & & \\
\hline & 143 & 286 & 571 & 857 & 1143 & 1429 & 1714 & 2000 & & & & & & & & & & & & & \\
\hline & 125 & 250 & 500 & 750 & 1000 & 1250 & 1500 & 1750 & 2000 & & & & & & & & & & & & \\
\hline & 111 & 222 & 444 & 667 & 889 & 1111 & 1333 & 1556 & 1778 & 2000 & & & & & & & & & & & \\
\hline 10 & 100 & 200 & 400 & 600 & 800 & 1000 & 1200 & 1400 & 1600 & 1800 & 2000 & & & & & & & & & & \\
\hline 11 & 91 & 182 & 364 & 545 & 727 & 909 & 1091 & 1273 & 1455 & 1636 & 1818 & 2000 & & & & & & & & & \\
\hline 12 & 83 & 167 & 333 & 500 & 667 & 833 & 1000 & 1. & 1333 & 1500 & 1667 & 1833 & 2000 & & & & & & & & \\
\hline 13 & 77 & 154 & 308 & 462 & 615 & 769 & 923 & 10 & 1231 & 1385 & 12 & 16 & 1 & 2000 & & & & & & & \\
\hline 14 & 71 & 143 & 286 & 429 & 571 & 714 & 857 & 10 & 3 & 1 & 1 & 1 & 1 & 1856 & 2000 & & & & & & \\
\hline 15 & 67 & 133 & 267 & 400 & 533 & 667 & 800 & 933 & 57 & 712 & 1 & 1 & 90 & 1 & 1867 & 2000 & & & & & \\
\hline 16 & 62 & 125 & 250 & 375 & 500 & 625 & 750 & 875 & 510 & 11 & 50 & 1 & 00 & 1 & 50 & 187 & 2000 & & & & \\
\hline 1 & 59 & 118 & 235 & 353 & 471 & 588 & 706 & 824 & 941 & 1059 & 1176 & 1 & 1412 & 29 & 1647 & 17 & 1882 & 20 & & & \\
\hline & 55 & 111 & 222 & 333 & 444 & 556 & 667 & 778 & 889 & 1000 & 1111 & 1222 & 1333 & 1444 & 1 & 1667 & 1778 & 18 & 2000 & & \\
\hline & 52 & 105 & 211 & 316 & 421 & 526 & 632 & 737 & 7. 842 & 947 & 1053 & 1 & 1263. & 1368 & 1 & 1579 & 1684 & 17 & 18 & 2000 & \\
\hline 20 & 50 & 100 & 200 & 300 & 400 & 500 & 600 & 700 & 800 & 900 & 1000 & 11 & 12 & 1300 & 14 & 15 & 1600 & 17 & 18 & 19 & 200 \\
\hline 21 & 47 & 95 & 190 & 286 & 381 & 476 & 571 & 667 & 762 & 857 & 952 & 10 & 11 & 12 & 13 & 14 & 1524 & 16 & 17 & 0 & 190 \\
\hline 22 & 4.5 & 91 & 182 & 273 & 364 & 455 & 545 & 636 & 727 & 818 & 909 & 10 & 1 & 1 & 12 & 13 & 14 & 1 & 1 & 1727 & 18 \\
\hline 2.3 & 43 & 87 & 174 & 261 & 348 & 435 & 521 & 608 & 695 & 782 & 869 & 6 & 1( & 1. & $1:$ & 13 & 1391 & & $1:$ & 1651 & 17 \\
\hline 24 & 41 & 83 & 167 & 250 & 333 & 417 & 500 & 583 & 667 & 750 & 833 & 917 & 1000 & 1083 & 1167 & 1250 & 1333 & 1417 & 1500 & 1583 & 166 \\
\hline 25 & 40 & 80 & 160 & 240 & 320 & 400 & 480 & 560 & 640 & 720 & 800 & 880 & 960 & 1040 & 1120 & 1200 & 1280 & 1360 & 1440 & 1520 & 1600 \\
\hline 26 & 38 & 77 & 154 & 231 & 308 & 385 & 462 & 538 & 3 615 & 692 & 769 & 846 & 923 & 1000 & 1077 & 1154 & 1231 & 1308 & 1385 & 1462 & 1538 \\
\hline 27 & 37 & 74 & 148 & 222 & 296 & 370 & 444 & 519 & ) 593 & 667 & 741 & 815 & 889 & 963 & 1037 & 1111 & 1185 & 1259 & 1333 & 1407 & 148 \\
\hline 28 & 35 & 71 & 143 & 214 & 286 & 357 & 429 & 500 & 571 & 643 & 714 & 786 & 857 & 929 & 1000 & 1071 & 1143 & 1214 & 12 & 1357 & 142 \\
\hline 3( & 33 & 67 & 133 & 200 & 267 & 333 & 400 & 467 & 7. 533 & 600 & 667 & 733 & 800 & 867 & 933 & 1000 & 1067 & 1133 & 1200 & 1267 & 133 \\
\hline & 29 & 57 & 114 & 171 & 229 & 286 & 343 & 400 & 457 & 514 & 571 & 629 & 686 & 743 & 800 & 857 & 914 & 971 & 1029 & 1086 & 114 \\
\hline 4 & 25 & 50 & 100 & 150 & 200 & 250 & 300 & 350 & 400 & 450 & 500 & 550 & 600 & 650 & 700 & 750 & 800 & 850 & 900 & 950 & 100 \\
\hline & 22 & 44 & 89 & 133 & 178 & 222 & 267 & 311 & 356 & 400 & 444 & 489 & 533 & 578 & 622 & 667 & 711 & 756 & 800 & 844 & 88 \\
\hline & 21 & 43 & 85 & 128 & 170 & 213 & 255 & 298 & 3340 & 383 & 426 & 468 & 511 & 553 & 596 & 638 & 681 & 723 & 766 & 809 & 85 \\
\hline & 21 & 42 & 83 & 125 & 167 & 208 & 250 & 292 & 333 & 375 & 417 & 458 & 500 & 542 & 583 & 625 & 667 & 708 & 750 & 792 & 8 \\
\hline & 20 & 41 & 82 & 122 & 163 & 204 & 245 & 286 & 327 & 367 & 408 & 449 & 490 & 53 & 571 & 612 & 65 & 694 & 73 & 776 & 81 \\
\hline & 20 & 40 & 80 & 120 & 160 & 200 & 240 & 280 & 320 & 360 & 400 & 440 & 480 & 520 & 560 & 600 & 640 & 680 & 720 & 760 & $80 C$ \\
\hline
\end{tabular}

1 The following expressions, when occurring in this bulletin, are used to mean as follows:

"Fertilizer analysis formula," or simply "analysis formula," the formulated statement of the percent ages of ammonia, phosphoric acid, and potash in a fertilizer. Thus 3-9-3 is the "analysis formula" of a ertilizer guaranteed to contain 3 per cent $\mathrm{NH}_{3}, 9$ per cent $\mathrm{P}_{2} \mathrm{O}_{5}$, and 3 per cent $\mathrm{K}_{2} \mathrm{O}$.

Fertilizer ratio," the formulated statement of the percentages of ammonia, phosphoric acid, and potash, in a fertilizer when expressed on the basis of the fertilizing elements alone.

Fertilizer formula," or "formula," a statement of the ingredients and weights of each required to make a ton of a mixed fertilizer.

${ }_{2}$ Compiled from data given in Table 2, Bull. 221, p. 15, Va. Agr. Expt. Sta., with additions. 
If it is desired to supply a fertilizer constituent, such as ammonia, from two or more single constituent materials, it is customary to decide arbitrarily beforehand on the percentage of the constituent in the fertilizer which shall be supplied by each material. The quantity of each material to be taken is then found directly in the usual way by reference to Table 1 .

When one or more of the materials used in a fertilizer contains more than one fertilizer constituent, the calculation of the mixture can most conveniently be done by listing the data in tabular form, as illustrated in Table 2. Of the materials listed in the table for use in a 3-8-3 mixture, three contain ammonia. If it is decided that the sodium nitrate shall supply kalf of the ammonia (or 30 pounds per ton of fertilizer) and the cottonseed meal and tankage 15 pounds each, then the weights of these materials required to yield these quantities of ammonia are 162, 200, and 177 pounds, respectively. But 200 pounds of cottonseed meal also contain 5.6 pounds of $\mathrm{P}_{2} \mathrm{O}_{5}$ and 3.4 pounds of $\mathrm{K}_{2} \mathrm{O}$, while 177 pounds of tankage contain 8.8 pounds of $\mathrm{P}_{2} \mathrm{O}_{5}$. The remaining 145.6 pounds of $\mathrm{P}_{2} \mathrm{O}_{5}$ and 56.6 pounds of $\mathrm{K}_{2} \mathrm{O}$ require, respectively, 910 pounds of acid phosphate and 283 pounds manure salt.

TABLE 2.-Method of listing data for 3-8-3 fertilizer mixture

\begin{tabular}{|c|c|c|c|c|c|c|c|}
\hline \multirow{2}{*}{ Materials } & \multicolumn{3}{|c|}{ Composition } & \multicolumn{3}{|c|}{ Constituents required } & \multirow{2}{*}{$\begin{array}{l}\text { Material } \\
\text { required }\end{array}$} \\
\hline & $\mathrm{NH}_{3}$ & $\mathrm{P}_{2} \mathrm{O}_{5}$ & $\mathrm{~K}_{2} \mathrm{O}$ & $\mathrm{NH}_{3}$ & $\mathrm{P}_{2} \mathrm{O}_{5}$ & $\mathrm{KO}_{2}$ & \\
\hline $\begin{array}{l}\text { Nitrate of soda } \\
\text { Cottonseed meal } \\
\text { Tankage } \\
\text { Acid phosphate } \\
\text { Manure salt }\end{array}$ & $\begin{array}{r}\text { Per cent } \\
18.5 \\
7.5 \\
8.5\end{array}$ & $\begin{array}{r}\text { Per cent } \\
2.8 \\
5.0 \\
16.0\end{array}$ & Per cent & $\begin{array}{r}\text { Pounds } \\
30.0 \\
15.0 \\
15.0\end{array}$ & $\begin{array}{r}\text { Pounds } \\
5.6 \\
8.8 \\
145.6\end{array}$ & $\begin{array}{r}\text { Pounds } \\
3.4 \\
56.6\end{array}$ & $\begin{array}{r}\text { Pounds } \\
162 \\
200 \\
177 \\
910 \\
283\end{array}$ \\
\hline $\begin{array}{l}\text { Total - } \\
\text { Filler- }\end{array}$ & & & & 60.0 & 160.0 & 60.0 & $\begin{array}{r}\text { 1. } 732 \\
268\end{array}$ \\
\hline & & & & & & & 2,000 \\
\hline
\end{tabular}

The general formula for the calculation of a fertilizer mixture of this kind may be expressed as follows:-

If $a=$ Percentage of $\mathrm{NH}_{3}$ in sodium nitrate

$a^{\prime}=$ Percentage of $\mathrm{NH}_{3}$ in cottonseed meal

$a^{\prime \prime}=$ Percentage of $\mathrm{NH}_{3}$ in tankage

$b=$ Percentage of $\mathrm{P}_{2} \mathrm{O}_{5}$ in cottonseed meal

$b^{\prime}=$ Percentage of $\mathrm{P}_{2} \mathrm{O}_{5}$ in tankage

$b^{\prime \prime}=$ Percentage of $\mathrm{P}_{2} \mathrm{O}_{5}$ in acid phosphate

$c=$ Percentage of $\mathrm{K}_{2} \mathrm{O}$ in cottonseed meal

$c^{\prime}=$ Percentage of $\mathrm{K}_{2} \mathrm{O}$ in manure salt

then for an $A-B-C$ fertilizer:

$X$, sodium nitrate required $=2,000 \frac{A / 2}{a}$

$X^{\prime}$, cottonseed meal required $=2,000 \frac{A / 4}{a^{\prime}}$

$X^{\prime \prime}$, tankage required $=2,000 \frac{A / 4}{a^{\prime \prime}}$

$Y$, acid phosphate required $=\frac{2,000 B-\left(b X^{\prime}+b^{\prime} X^{\prime \prime}\right)}{b^{\prime \prime}}$

$Z$, manure salt required $=\frac{2,000 C-c X^{\prime}}{c^{\prime}}$. 
When each of the three fertilizing elements of a mixed fertilizer is supplied by one or more simple constituent materials, with or without the addition of two or three constituent materials, considerable leeway is possible in the proportions of the like constituent materials which may be taken, and in such cases there is little or no advantage in the use of a general formula for the calculation of such mixtures.

As the number of materials, particularly single-constituent materials, available for a fertilizer mixture is reduced, the range of fertilizer analysis formulae which they are capable of making is also reduced, and the difficulty of the ordinary arithmetic method of calculating any given mixture may be greatly increased.

It is likely that in the future fewer materials will be used in mixed fertilizers, and that the concentration of these materials will be greater. This condition is to be expected from reasons to be discussed later. The object of the present bulletin is, therefore, to outline simple methods for determining the possible fertilizer ratios which may be made from concentrated fertilizer materials, and for calculating the quantities required for any given fertilizer analysis formula.

\section{THE TRIANGULAR SYSTEM FOR FERTILIZER MIXTURES}

From the trade standpoint the value of a complete fertilizer, in the present development of the fertilizer industry, is based entirely on the available ammonia, phosphoric acid, and potash present, and is independent of the number of materials in the mixture. Variations in the composition of mixed fertilizers may therefore be represented by use of a system of three coordinates corresponding to the three variables, ammonia, phosphoric acid, and potash. Such a system of coordinates is the triangular system ${ }^{3}$ and the range of fertilizer ratios which can be made from fertilizer materials can be readily determined with the aid of triangular section paper as represented in Plate I.

The corners $A, B$, and $C$ of the triangle represent 100 per cent of $\mathrm{NH}_{3}, \mathrm{P}_{2} \mathrm{O}_{5}$, and $\mathrm{K}_{2} \mathrm{O}$, respectively. The distance from each corner of the triangle to the opposite side is divided into 100 equal parts. The sum of the distances along the respective perpendiculars, from any point within the triangle to the opposite sides, will always amount to 100 of these divisions. Each point within the triangle will therefore represent a definite mixture of all three constituents in such proportion as to total 100 per eent. Thus the point $E$, being 25,50 , and 25 divisions from the sides $B C, C A$, and $A B$, respectively, represents a mixture in which 25 per cent of the total fertilizing material is $\mathrm{NH}_{3}, 50$ per cent is $\mathrm{P}_{2} \mathrm{O}_{5}$, and 25 per cent is $\mathrm{K}_{2} \mathrm{O}$. This point, therefore, represents a $25-50-25$ fertilizer ratio, or any submultiple of this ratio, such as 4-8-4. Each side of the triangle represents varying mixtures of the two constituents represented by the adjacent corners but none of that of the opposite corner. Thus the side $A B$ represents mixtures containing varying amounts of $\mathrm{NH}_{3}$ and $\mathrm{P}_{2} \mathrm{O}_{5}$ but no $\mathrm{K}_{2} \mathrm{O}$; and the side $C A$ varying amounts of $\mathrm{K}_{2} \mathrm{O}$ and $\mathrm{NH}_{3}$ but no $\mathrm{P}_{2} \mathrm{O}_{5}$. Any particular point on a side represents a definite mixture of the two constituents represented. The point $D$ on the side $A B$, for example, being 40 divisions from $B C$ and 60 divisions from $A C$, corresponds to a fertilizer mixture which contains 40 per cent of the total fertilizing elements as $\mathrm{NH}_{3}, 60$ per cent as $\mathrm{P}_{2} \mathrm{O}_{5}$ and 0 per cent $\mathrm{K}_{2} \mathrm{O}$.

The triangular diagram has been used by Schreiner and Skinner (J. Am. Soc. Agron. Vol. 10, p $246,1918)$ in their experimental fertilizer mixtures for studying the effect on plants of different ratios of the fertilizing elements, ammonia, phosphoric acid, and potash. 
A material such as sodium nitrate, in which the $\mathrm{NH}_{3}$ amounts to 100 per cent of the fertilizing elements present, will be represented on the triangle by the point $A$. Similarly, acid phosphate will correspond to the point $B$, and a potash salt to the point $C$. As the lines joining these three points coincide with the boundary lines of the triangle, it follows that submultiples of any fertilizer ratio whatever may be made by combinations of these three materials. The maximum fertilizer analysis formula possible for any given ratio is obtained by multiplying by the factor $\frac{2000}{X+Y+Z}$. Thus, if the sodium nitrate contains 18 per cent $\mathrm{NH}_{3}$, the acid phosphate 16 per cent $\mathrm{P}_{2} \mathrm{O}_{5}$, and the potash salt 20 per cent $\mathrm{K}_{2} \mathrm{O}$; then, for a 4-8-4 mixture, $X=444, Y=$ $1000, Z=400$, and $X+Y+Z=1844$. The maximum possible analysis formula, corresponding to the mixture $4-8-4$, that can be made from these materials is, therefore, $\left[\frac{2000}{1844}(4-8-4)\right]$ or $4.34-8.68-4.34$.

A material, for example a tankage containing, say, 8.5 per cent $\mathrm{NH}_{3}$ and 5 per cent $\mathrm{P}_{2} \mathrm{O}_{5}$, would have 63 per cent of its fertilizing elements in the form of $\mathrm{NH}_{3}$ and 37 per cent as $\mathrm{P}_{2} \mathrm{O}_{5}$, and would be represented in the triangle on the side $A B$ by the point $F$. Submultiples of all ratios which fall within the triangle $F C B$ can therefore be made from this material in combination with acid phosphate, and a potash salt, while those which fall outside this triangle, such as the analysis formula 5-2-3 corresponding to the ratio 50-20-30 represented by the point $G$, can not be made. $G$, however, falls within the triangle $F C A$, and, therefore, submultiples of the ratio 50-20-30 can be obtained by combinations of tankage and potash salt with a nitrogenous material.

If the ammonia in a fertilizer mixture is to be obtained from nitrate of soda, cottonseed meal, and tankage, in the proportions given in Table 2, then 2 of a total of 4 parts of $\mathrm{NH}_{3}$ will be present in the mixture as nitrate, 1 as cottonseed meal, and 1 as tankage. But the quantities of the two last materials, which contain 1 part each of $\mathrm{NH}_{3}$, also contain 0.96 part of $\mathrm{P}_{2} \mathrm{O}_{5}$ and 0.23 part of $\mathrm{K}_{2} \mathrm{O}$. The mixture of these three materials therefore contains 77 per cent of the fertilizer constituents as $\mathrm{NH}_{3}, 19$ per cent as $\mathrm{P}_{2} \mathrm{O}_{5}$, and 4 per cent as $\mathrm{K}_{2} \mathrm{O}$, and may be represented in Plate $\mathrm{I}$ by the point $H$. Submultiples of all ratios which fall within the triangle $H B C$ can be made by combinations of these three materials with acid phosphate and potash salt. The maximum fertilizer analysis formula that can be made of any of these ratios is obtained in the usual way by multiplying by the fraction $\frac{2000}{X+X^{\prime}+X^{\prime \prime}+Y+Z}$.

\section{FACTORS THAT INFLUENCE THE CONCENTRATION OF FERTILIZERS}

The principal sources of each of the three essential constituents of fertilizers are saline or mineral deposits and industrial by-products. Phosphate rock is the principal source of phosphoric acid, but the latter also occurs in bones, fish scrap, and cottonseed meal. The potash comes from saline and mineral deposits, and industrial wastes such as cement-mill dust, tobacco stems, and sugar-beet liquors. The nitrogen is obtained from even more diverse sources such as the nitrate deposits of Chile and the waste products of many industries. 
The percentages of nitrogen, phosphoric acid, and potash in almost all these raw materials are comparatively low. No nitrogen deposit or waste material contains more than 15 per cent of nitrogen. The Alsatian potash deposits may run as high as 20 per cent of potash, but there are no known deposits or materials in this country which contain more than 12 per cent of potash. Phosphoric acid occurs in fairly high concentration in phosphate rock, but in the process of manufacturing commercial acid phosphate the concentration is reduced to about 16 per cent.

Other materials, such as garbage tankage, may contain as little as 3 per cent of available plant food. When the products from these various sources are compounded into mixed fertilizer, the concentration of the mixture must always be less than that of the most concentrated material used in its preparation. Complete fertilizers containing as low as 10 per cent of total plant food constituents have been made, and for many years the average composition of the commercial mixed fertilizers could be represented by the analysis formula 2-8-2, i. e., 2 per cent $\mathrm{NH}_{3}, 8$ per cent $\mathrm{P}_{2} \mathrm{O}_{5}$, and 2 per cent $\mathrm{K}_{2} \mathrm{O}$, by weight in the mixture.

If low-grade materials could be obtained in unlimited quantity near all points of consumption, there would perhaps be little economy in increasing their concentration. It is recognized that in the use of such materials there may be advantages which are lacking in the use of more concentrated materials: (1) A market is afforded for industrial by-products which would not have a market otherwise; (2) the fertilizing constituents in these materials may vary greatly in availability and thus serve to supply food to the plant throughout the growing season; (3) while many constituents of low-grade materials, such as sulphur and different forms of organic matter, add nothing to the commercial value of a fertilizer, they may nevertheless have a beneficial effect on many soils; (4) many low-grade materials have properties which improve the physical condition of the whole mixture; and (5), small amounts of plant food per acre can be applied more conveniently in the form of low-grade than very high-grade materials. It happens, however, that the use of fertilizers is now increasing most rapidly in those States that have a limited supply of many fertilizer materials, and the cost of handling and transporting low-grade fertilizers is a very serious disadvantage to their use in such localities.

This disadvantage has long been recognized, and considerable advance has already been made in increasing the concentration of many materials which require shipment to a distance. Commercial Chilean caliche, containing as low as 15 per cent sodium nitrate, is refined before shipment to a product analyzing 90 to 95 per cent sodium nitrate. Some of the German potash salts shipped to this country have been concentrated from about 9 per cent to 60 per cent potash, while a large proportion of the western potash salts produced since the war have been refined from a relatively low-grade material to one containing as high as 62 per cent potash. By the proper selection of these and other materials, the average analysis of mixed fertilizers has undergone a gradual increase in the last 10 years, amounting to about 30 per cent.

It is generally admitted, however, that fertilizers of still higher concentration are desirable, and there is now an active campaign to raise the analyses of mixed fertilizers, and to limit the number of analysis formulae. Action along these lines was taken at five con- 
ferences recently held at Chicago, Boston, Baltimore, Shreveport, and Atlanta, attended by agronomists of various States and representatives of manufacturers selling fertilizers in the States mentioned on p. 12. At these conferences, 52 analysis formulae ${ }^{4}$ were recommended, varying from 14 to 32 per cent in plant food constituents, with an average of 18 per cent. These recommendations, if put into practice, would increase the concentration of fertilizers about 51 per cent over the average mixed fertilizer of a few years ago.

In addition to the cost of handling and transporting, there still remains a more serious objection to dependence on low-grade material for future expansion in fertilizer manufacture. This is the question of supply. A number of materials, as cottonseed meal, tankage, etc., which have been used extensively in fertilizers, are being used more and more as feed for livestock. "The output of these industrial byproducts is limited by the production of the principal products and can not be increased independently of the latter to meet an increased demand for the by-product.

To meet the probable future needs for nitrogenous materials, attention is now being directed to a source that is neither mineral deposit nor industrial by-product-namely, the nitrogen cf the air.

When atmospheric nitrogen is fixed as ammonia, nitrogen is obtained in one of its most concentrated combinations. Ammonia, as such, however, can not be used directly as a commerical fertilizer; it becomes suited for this purpose only when neutralized with an acid.

Investigations by the Bureau of Soils, ${ }^{5}$ now commercially utilized, have shown the feasibility of the industrial production of phosphoric acid by volatilization from phosphate rock, and the probable direct competition of this procedure with the sulphuric acid method for the treatment of phosphate rock. From the fertilizer standpoint, the newer method has the advantage of directly yielding an acid of a concentration most suitable for combining with ammonia, and for making, by substitution for sulphuric acid, many other concentrated materials such as the phosphates of sodium and potassium.

The manufacture of fixed nitrogen and of phosphoric acid thus provides the means for making many high-analysis fertilizer materials which may have wide application in the future if the supply of lowgrade material falls short of the demand.

\section{CONCENTRATED FERTILIZER COMPOUNDS}

In Table 3 are given the chemical and physical properties of a number of inorganic materials which contain one or more of the essential constituents of fertilizers. The incompleteness of the table is due to the fragmentary nature of the data recorded in the literature, which, in addition, are often very conflicting. Some of the materials listed are now widely used in fertilizers. The data for the others are supplied for the purpose of showing which materials may have future application in increasing the concentration of fertilizers and which have properties that prevent their use for this purpose unless a satisfactory way is found to eliminate the properties that are considered objectionable.

${ }^{4}$ The Standard Analyses. Anon. Am. Fertilizer, vol. 58, No. 4, p. 27, 1923; High Analysis. Anon. Am. Fertilizer, vol. 59 , No. 9 , p. $28,1923$.

5 The Use of the Cottrell Precipitator in Recovering the Phosphoric Acid Evolved in the Volatilization Method of Treating Phosphate Rock. W. H. Ross, J. N. Carothers, and A. R. Merz. J. Ind. Chem., vol. 9, p. 26-31, 1917; Electric Furnace Smelting of Phosphate Rock and Use of the Cottrell Precipitator in Collecting the Volatilized Phosphoric Acid. J. N. Carothers, J. Ind. Eng. Chem., vol. 10, p. 35-8, 1918; Investigations of the Manufacture of Phosphoric Acid by the Volatilization Process. W. H. Waggaman, H. W. Easterwood, and T. B. Turley. U. S. D. A. Dept. Bull. 1179, p.1-53, 1923. 
BULLETIN 1280, U. S. DEPARTMENT OF AGRICULTURE

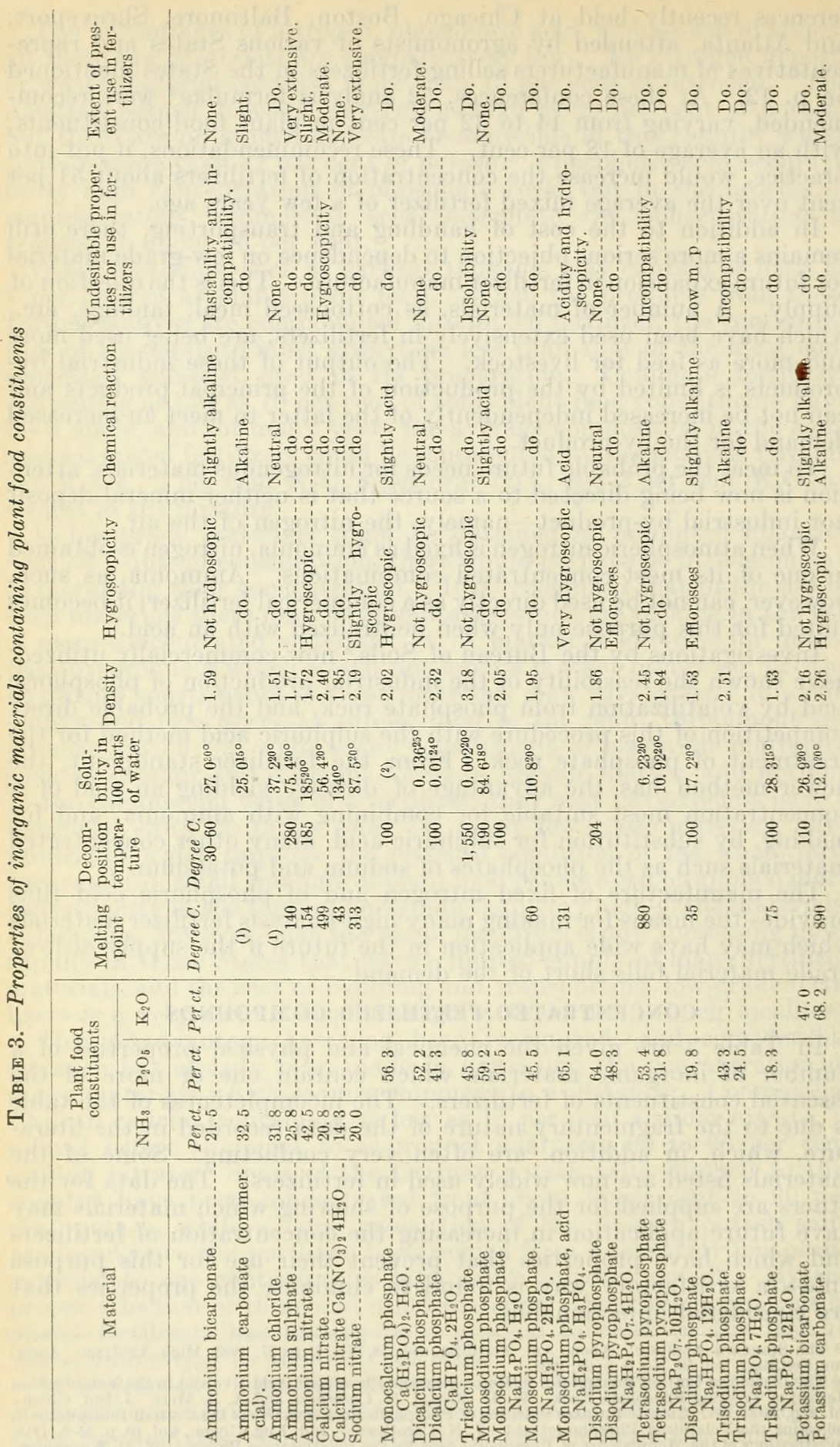




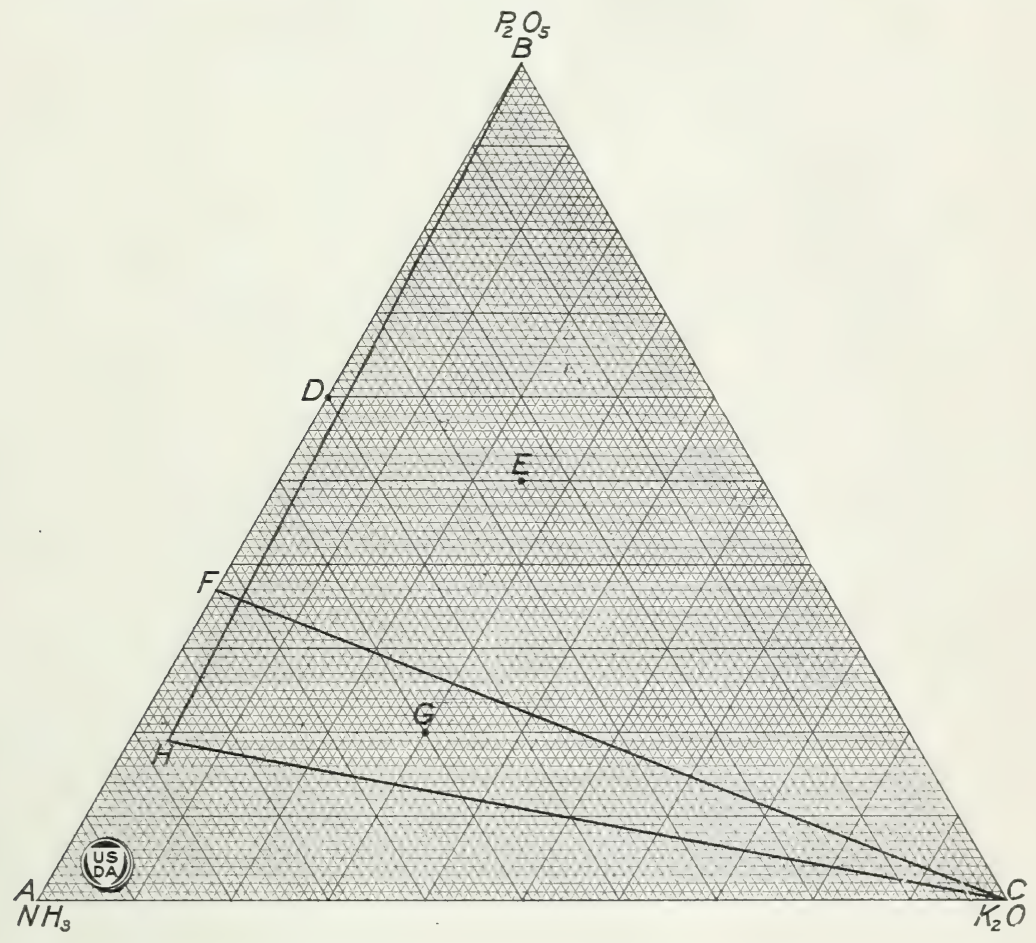

Triangular diagram illustrating the graphical representation of fertilizer ratios, and the ratios obtainable from fertilizer materials of given composition 


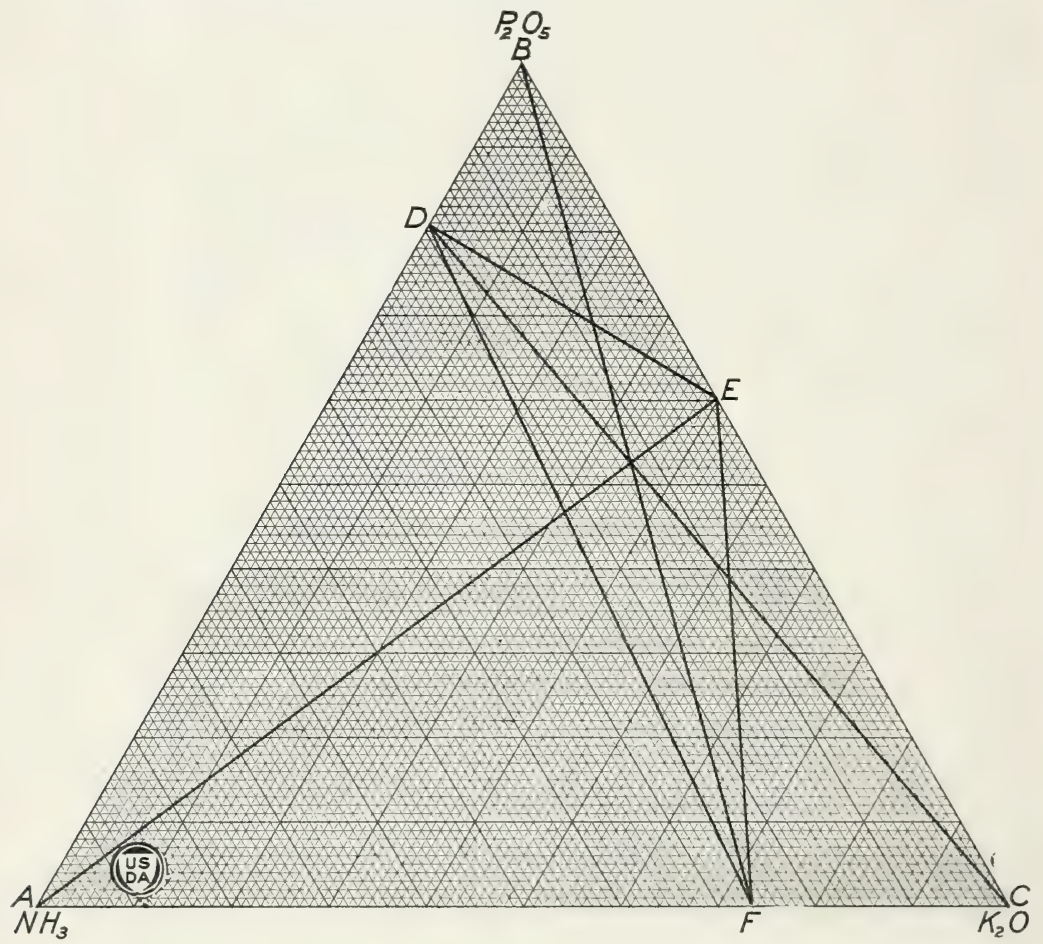

Triangular diagram showing fertilizer ratios obtainable from combinations of monoammonium phosphate, monopotassium phosphate, and potassium nitrate, as well as those obtainable from combinations of these compounds with single fertilizer constituent materials 

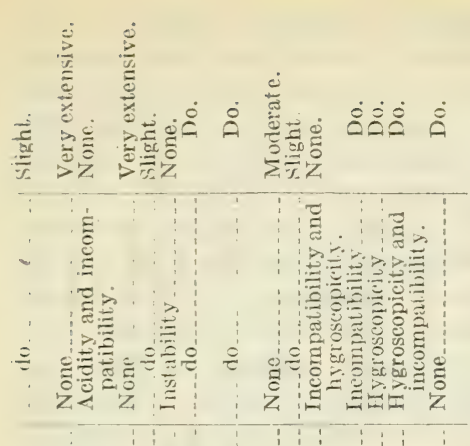

๖

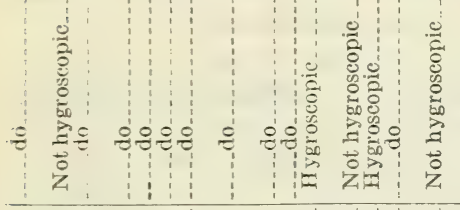

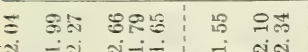

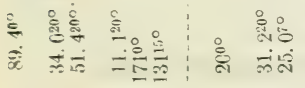

\&

§

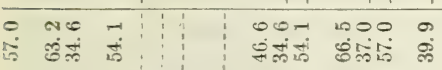

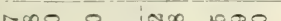

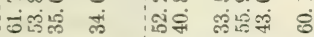

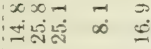

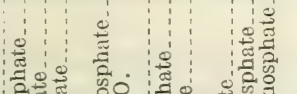


Among the concentrated materials listed in Table 3 are the salts. monoammonium phosphate, monopotassium phosphate, and potassium nitrate. These compounds contain combinations of all three fertilizer constituents in groups of two, and all have chemical and physical properties which make them admirably suited for use in fertilizers. Potassium nitrate has long been used to a limited extent in fertilizers, and is obtained from Chilean nitrate and other sources. It may also be prepared by treating potassium chloride with nitric acid such as that produced in the fixation of nitrogen. Monoammonium phosphate is now being used to some extent in high-grade fertilizers, and may be prepared by neutralizing ammonia, such as obtained in the fixation of nitrogen, with phosphoric acid. The use of monopotassium phosphate in fertilizers has been limited to experimental tests only. It may be prepared from potassium chloride and phosphoric acid. The percentage composition of these salts is giren in Table 4.

TABLE 4.-Composition of concentrated fertilizer salts

\begin{tabular}{|c|c|c|c|c|c|c|}
\hline \multirow{3}{*}{ Salt } & \multicolumn{6}{|c|}{ Composition on basis of - } \\
\hline & \multicolumn{3}{|c|}{ Total material } & \multicolumn{3}{|c|}{ Fertilizing elements present } \\
\hline & $\mathrm{NH}_{3}$ & $\mathrm{P}_{2} \mathrm{O}_{5}$ & $\mathrm{~K}_{2} \mathrm{O}$ & $\mathrm{NH}_{3}$ & $\mathrm{P}_{2} \mathrm{O}_{5}$ & $\mathrm{~K}_{2} \mathrm{O}$ \\
\hline $\begin{array}{l}\text { Monoammonium phosphate, } \mathrm{NH}_{4} \mathrm{H}_{2} \mathrm{PO}_{4} \\
\text { Monopotassium phosphate } \mathrm{K} \mathrm{H}_{2} \mathrm{PO}_{4}\end{array}$ & $\begin{array}{r}\text { Per cent } \\
14.80\end{array}$ & \multirow[t]{2}{*}{$\begin{array}{r}\text { Per cent } \\
61.72 \\
52.18\end{array}$} & Per cent & $\begin{array}{r}\text { Per cent } \\
19.34\end{array}$ & \multirow[t]{2}{*}{$\begin{array}{r}\text { Per cent } \\
80.66 \\
60.14\end{array}$} & Per cent \\
\hline $\begin{array}{l}\text { Monopotassium pnosphate, } \mathrm{K} \mathrm{H}_{2} \mathrm{PO}_{4} \\
\text { Potassium nitrate, } \mathrm{KNO}_{3}\end{array}$ & 16.85 & & 46. 58 & 26.57 & & -4.43 \\
\hline
\end{tabular}

\section{FERTILIZER MIXTURES FROM CONCENTRATED MATERIALS}

Applying the triangular system to fertilizer mixtures from concentrated materials, it is seen from the percentage values given in Table 4 that monoammonium phosphate corresponds to the point $D$ in the triangle of Plate II; monopotassium phosphate to the point $E$ and potassium nitrate to the point $F$. These three materials may therefore be used to make submultiples of all fertilizer ratios falling within the triangle $D E F$. In the same way, triangles may be drawn corresponding to combinations of any two of these compounds with a nitrogen, phosphoric acid, or potash salt. Thus the triangle $A D E$ incloses all possible ratios that can be made with mixtures of monoammonium phosphate, monopotassium phosphate, and a nitrogen compound; the triangle $C D E$ all ratios that can be prepared from the same two compounds and a potash salt, and the triangle $B D E$ all the ratios that can be made from these two compounds and a phosphatic material, such as acid phosphate.

When each of three materials selected for a mixture contains two fertilizing elements, then the amount of each required to give a ton of a fertilizer of any analysis formula which they are capable of making, as shown by the triangle method, may be calculated at follows:

If $A, B$, and $C$ are the percentages respectively of the $N H_{3}, \mathrm{P}_{2} \mathrm{O}_{5}$. and $\mathrm{K}_{2} \mathrm{O}$ desired in the mixed fertilizer, and-

$X=$ Weight of material containing $a$ per cent $\mathrm{NH}_{3}$, and $b$ per cent $\mathrm{P}_{2} \mathrm{O}_{5}$. 
$Y=$ Weight of material containing $b^{\prime}$ per cent $\mathrm{P}_{2} \mathrm{O}_{5}$, and $c$ per cent $\mathrm{K}_{2} \mathrm{O}$.

$Z=$ Weight of material containing $c^{\prime}$ per cent $\mathrm{K}_{2} \mathrm{O}$, and $a^{\prime}$ per cent $\mathrm{NH}_{3}$.

$$
\text { Then } \begin{aligned}
X & =2000 \frac{b^{\prime} c^{\prime} A+a^{\prime} c B-a^{\prime} b^{\prime} C}{a b^{\prime} c^{\prime}+a^{\prime} b c} \\
Y & =\frac{2000 B-b X}{b^{\prime}}, \text { and } \\
Z & =\frac{2000 C-c Y}{c^{\prime}}
\end{aligned}
$$

For the particular case where the three materials used are monoammonium phosphate, monopotassium phosphate, and potassium nitrate respectively,

$\mathrm{X}$, monoammonium phosphate $=2000 \frac{2430.54 A+582.84 B-879.23 C}{71945}$

$\mathrm{Y}$, monopotassium phosphate $=\frac{2000 B-61.72 X}{52.18}$

Z, potassium nitrate $=\frac{2000 C-34.6 Y}{46.58}$

The number of fertilizer ratios it is possible to make from these materials is limited, as already explained, and the same is true of any three materials which contain two constituents each. However, by successively combining these materials in pairs with ammonia, phosphoric acid, and potash salts, nine possible combinations are obtained and can be used, by varying the materials in any combination, to make any fertilizer ratio whatever. In Table 5 are given expressions for calculating for each of these nine combinations the quantities of the materials required for any fertilizer formula falling within the triangle representing the combination in Plate II.

TABLE 5.-Expressions for calculating the quantities of material required for a

\begin{tabular}{|c|c|c|c|c|c|c|}
\hline Mixture of- & $x$ & $Y$ & $Z$ & $\mathrm{M}_{\mathrm{NH}_{3}}$ & $\mathrm{M}_{\mathrm{K}_{2} \mathrm{O}}$ & $\mathrm{MI}_{\mathrm{P}: \mathrm{O}_{5}}$ \\
\hline $\begin{array}{l}X+Y+\mathrm{M}_{\mathrm{K}_{2} \mathrm{O}^{\cdots}} \\
X+Y+\mathrm{M}_{\mathrm{NH}_{3}} \cdots \\
X+Y+\mathrm{M}_{\mathrm{P}_{2} \mathrm{O}} \cdots \\
Y+Z+\mathrm{M}_{\mathrm{NH}_{3}} \cdots \\
Y+Z+\mathrm{M}_{\mathrm{P}_{2} \mathrm{O}_{5}} \\
Y+Z+\mathrm{M}_{\mathrm{K}_{2} \mathrm{O}^{\cdots}} \\
Z+X+\mathrm{M}_{\mathrm{K}_{2} \mathrm{O}^{\cdots}} \\
Z+X+\mathrm{M}_{\mathrm{NH}_{3}} \\
Z+X+\mathrm{M}_{\mathrm{P}_{2} \mathrm{O}_{5}}\end{array}$ & $\left|\frac{\frac{2,000 A}{a}}{\frac{2,000 B-b^{\prime} Y}{b}}\right| \frac{2,000 A}{a} \mid$ & \begin{tabular}{|l}
$\frac{2,000 B-b X}{b^{\prime}}$ \\
$\frac{2,000 C}{c}$ \\
$\frac{2,000 C}{c}$ \\
$\frac{2,000 B}{b^{\prime}}$ \\
$\frac{2,000 C-c^{\prime} Z}{c}$ \\
$\frac{2,000 B}{b^{\prime}}$
\end{tabular} & $\begin{array}{c}\frac{2,000 C-c Y}{c^{\prime}}- \\
\frac{2,000 A}{a^{\prime}} \\
\frac{2,000 A}{a^{\prime}} \\
\frac{2,000 A-a X}{a^{\prime}} \\
\frac{2,000 C}{c^{\prime}} \\
\frac{2,000 C}{c^{\prime}}\end{array}$ & $\begin{array}{l}\frac{2,000 A-a^{\prime} Z}{a^{\prime \prime}} \\
\frac{2,000 A-a^{\prime} Z-a X}{a^{\prime \prime}}\end{array}$ & $\frac{2,000 C-c Y-c^{\prime} Z}{c^{\prime \prime}}$ & $\begin{array}{l}\frac{2,000 B-b X-b^{\prime} Y}{b^{\prime \prime}} \\
\frac{2,000 B-b^{\prime} Y}{b^{\prime \prime}}\end{array}$ \\
\hline
\end{tabular}
ton of an $A-B-C$ fertilizer when materials that contain two fertilizing elements are combined in pairs with an $\mathrm{NH}_{3}, \mathrm{P}_{2} \mathrm{O}_{5}$, or $\mathrm{K}_{2} \mathrm{O}$ salt

$X$, quantity of material containing $a$ per cent $\mathrm{NH}_{3}$ and $b$ per cent $\mathrm{P}_{2} \mathrm{O}_{5}$

$Y$, quantity of material containing $b^{\prime}$ per cent $\mathrm{P}_{2} \mathrm{O}_{5}$ and $c$ per cent $\mathrm{K}_{2} \mathrm{O}$.

$Z$, quantity of material containing $c^{\prime}$ per cent $\mathrm{K}_{2} \mathrm{O}$ and $a^{\prime}$ per cent $\mathrm{NH}_{3}$

$\mathrm{M}_{\mathrm{NH}_{3}}$, quantity of material containing $a^{\prime \prime}$ per cent $\mathrm{NH}_{3}$.

$\mathrm{M}_{\mathrm{P}_{2} \mathrm{O}_{5}}$, quantity of material containing $b^{\prime \prime}$ per cent $\mathrm{P}_{2} \mathrm{O}_{5}$.

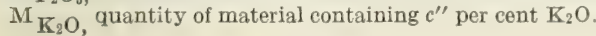




\section{STANDARD FERTILIZER MIXTURES FROM CONCENTRATED MATERIALS}

In Table 6 are listed the different fertilizer analrsis formulae recommended by the five agricultural conferences alreadr referred to for adoption. The States represented at these different conferences were: (A) Maine, New Hampshire, Vermont, Massachusetts, Rhode Island, and Connecticut; (B) Nerr York, Pennstrania, New Jerser, Delaware. Marrland, Virginia, and Test Tirginia: (C) Ohio. Missouri, Michigan, Indiana, and Tisconsin; (D) Arkansas, Texas, and Louisiana: (E) North Carolina, South Carolina, and Georgia.

TABLE 6.-Fertilizer-analysis formulae recommended by fine regional agricultural conferences for adoption

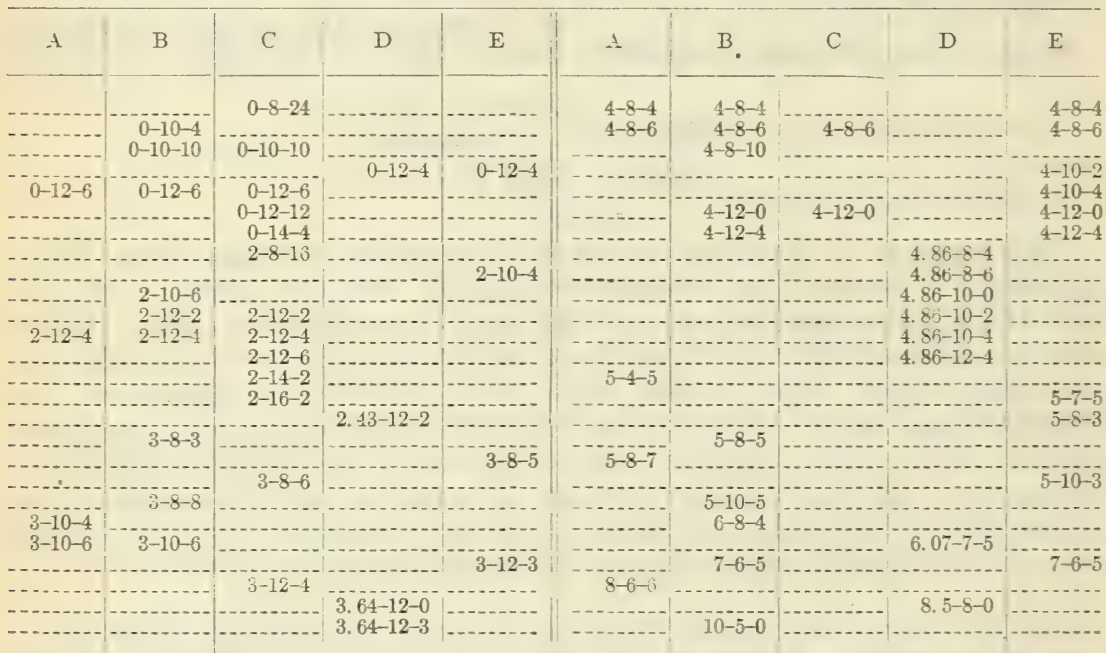

The ratios corresponding to each of these analysis formulae are plotted as points in the triangle of Plate III. By plotting also the lines, or triangles corresponding to any desired materials combined in groups of two or three, it may be seen at a glance what analrsis formula can be made from any given materials. Thus 17 of the 52 standard analysis formulae plotted in Plate III fall within the triangle $D E F$ and may, therefore, be prepared from combinations of monoammonium phosphate, monopotassium phosphate, and potassium nitrate. Nineteen other analysis formulae fall within the triangle $A D F$ and may be prepared from combinations of monoammonium phosphate, potassium nitrate, and an ammonium salt. The location of the remaining 16 analysis formulae shows in a similar way what materials máy be taken for their preparation. Of these 16 formulae 12 contain but two fertilizing elements. It may be noted also that a number of the analysis formulae fall within several triangies, indicating that they may be made by different combinations. Thus the analysis formula 3-10-6, numbered 22 in Plate III, falls within the four triangles $D E F, A D E, D F B$, and $D F C$, and may be prepared from monoammonium phosphate and monopotassium phosphate in combination with (1) an ammonium salt or (2) potassium nitrate: or from monoammonium phosphate and potassium nitrate in combination with (3) a phosphoric-acid salt or (4) potash salt. 


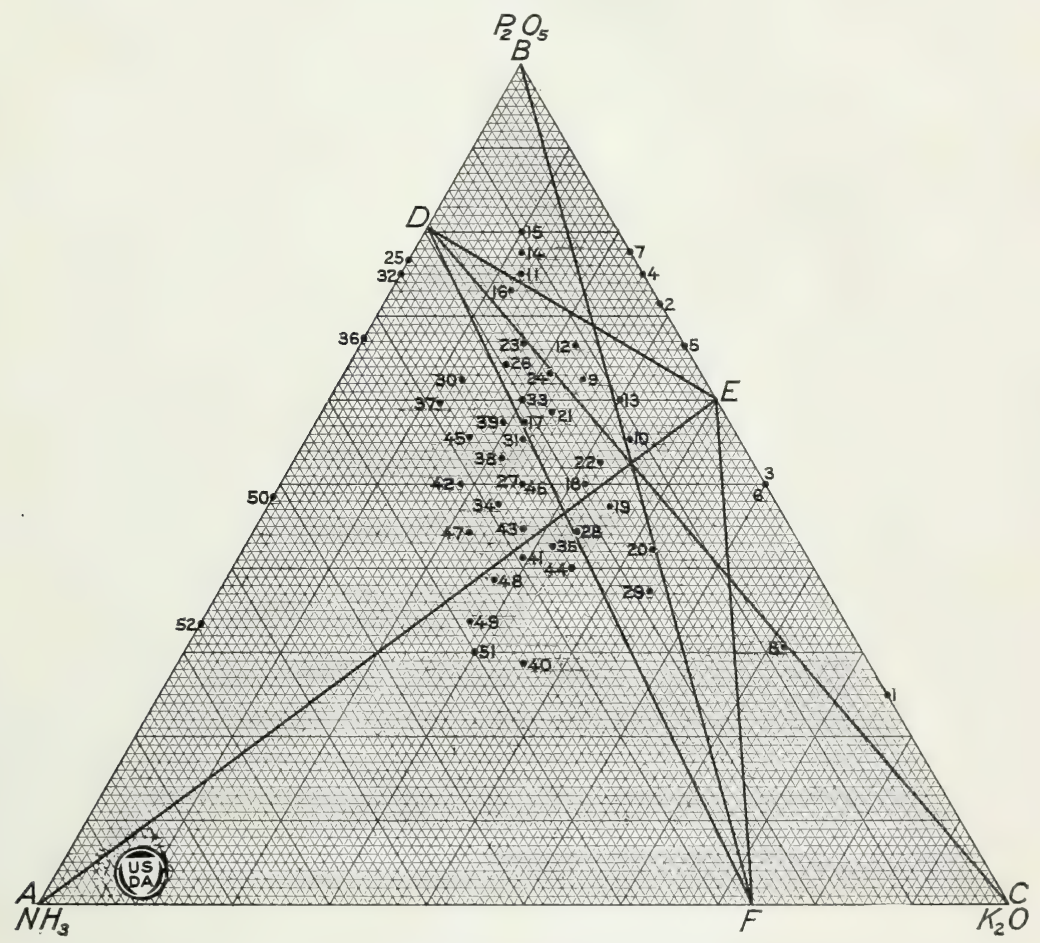

Showing the location of the fertilizer ratios of 52 standard high-analysis fertilizers on the diagram of Plate II 

The quantities of these or any other materials required in the preparation of this or any other analysis formula may be calculated by means of the expressions given above.

In Table 7, by way of illustration, are given the weights of monoImmonium phosphate, monopotassium phosphate, and potassium nitrate required for a ton of mixed fertilizer when combined together or taken in pairs with an ammonium. phosphoric-acid, or potash salt for the preparation of the standard fertilizer analrsis formulae listed abore. The weights of the materials giren in the table hare been calculated on the basis of 100 per cent purity. In the case of the commercial preparation of fertilizer mixtures, it will be necessary to diride the weights giren in the table by the percentage of purity of the fertilizer material, and multiply by 100, to determine what quantity of the commercial material to use.

TABLE 7.-Weights of materials which may be used in making a ton of standard fertilizers

\begin{tabular}{|c|c|c|c|c|c|c|c|c|}
\hline \multirow{2}{*}{$\underset{\text { ber }}{\text { Num- }}$} & \multirow{2}{*}{$\begin{array}{l}\text { Analysis } \\
\text { formula }\end{array}$} & \multirow{2}{*}{ 1. Ratio } & \multirow{2}{*}{$\mathrm{NH}_{4} \mathrm{H}_{2} \mathrm{PO}_{4}$} & \multirow{2}{*}{$\mathrm{KH}_{2} \mathrm{PO}_{4}$} & \multirow{2}{*}{$\mathrm{KNO}_{3}$} & \multicolumn{3}{|c|}{$\begin{array}{l}\text { Fertilizer constituents sup- } \\
\text { plied by other materials }\end{array}$} \\
\hline & & & & & & $\mathrm{NH}_{3}$ & $\mathrm{~K}_{2} \mathrm{O}$ & $\mathrm{P}_{2} \mathrm{O}_{5}$ \\
\hline & & & & Pounds & Pounds & Pounds & Pounds & Pounds \\
\hline $\begin{array}{l}1 \\
2\end{array}$ & $\begin{array}{l}0-8-24 \\
0-10-4\end{array}$ & $\begin{array}{r}0-25-75 \\
0-71.43-28.57\end{array}$ & & $\begin{array}{l}306.6 \\
231.3\end{array}$ & & & 374.0 & 79.3 \\
\hline 3 & $0-10-10$ & $0-50-50$ & & 383.3 & & & 67.4 & \\
\hline 4 & $0-12-4$ & $0-75-25$ & & 231.3 & & & . & 119.3 \\
\hline 5 & $0-12-6$ & $0-66.67-33.33$ & & 346.9 & & & & 59. 0 \\
\hline 6 & $\begin{array}{r}0-12-12 \\
0-14-4\end{array}$ & $\begin{array}{r}0-50-50 \\
0-77.78-22.22\end{array}$ & & $\begin{array}{r}459 \\
231\end{array}$ & & & 80.9 & 159.3 \\
\hline $\begin{array}{l}7 \\
8\end{array}$ & $\begin{array}{l}0-14-4 \\
2-8-16\end{array}$ & $\begin{array}{r}0-77.78-22.22 \\
7.69-30.77-61.54\end{array}$ & 259.2 & 23 & 9.5 & & 315.6 & 159.3 \\
\hline 8 & $2-8-16$ & $7.69-30.77-61.54$ & & 306.6 & 237.4 & & 103.4 & \\
\hline 9 & $2-10-4$ & 12. 5-62. 5-25 & 199.4 & 147.4 & & & & \\
\hline $\begin{array}{l}9 \\
9\end{array}$ & $\begin{array}{l}2-10-4 \\
2-10-4\end{array}$ & $\begin{array}{l}12.5-62 . \\
12.5-62 .\end{array}$ & $\begin{array}{l}128.5 \\
270.3\end{array}$ & $\begin{array}{r}231.3 \\
63.6\end{array}$ & & .0 & 58.0 & \\
\hline 9 & $2-10-4$ & $12.5-62$ & 75.0 & & 171.7 & & & 153.7 \\
\hline 10 & $2-10-6$ & $11.11-55.56-3$ & 150.5 & 205.3 & 105.2 & & & \\
\hline 1 & $\begin{array}{r}2-10-6 \\
2-10-6\end{array}$ & $-55,56-$ & 30.8 & $\begin{array}{r}346.9 \\
27.5\end{array}$ & 2373 & 5 & & 185,7 \\
\hline $\begin{array}{l}10 \\
10\end{array}$ & $\begin{array}{l}2-10-6 \\
2-10-6\end{array}$ & $\begin{array}{l}11.11-55.56-33.33 \\
11.11-55.56-33.33\end{array}$ & 270.3 & 63.6 & 237.3 & & 98.1 & 185.7 \\
\hline 11 & $2-12-2$ & 12. & 270.3 & 115. 7 & & & & 12.9 \\
\hline 11 & $2-12-2$ & 12 & 172.3 & & 85.9 & & -. & 133. \\
\hline 12 & $2-12-4$ & 11. $11-66.67-2$ & $\begin{array}{l}231.8 \\
193.3\end{array}$ & 185. 7 & & 4 & & \\
\hline $\begin{array}{l}12 \\
12\end{array}$ & $\begin{array}{l}2-12-4 \\
2-12-4\end{array}$ & $\begin{array}{l}11.1 \\
11.1\end{array}$ & $\begin{array}{r}193.3 \\
75.0\end{array}$ & 2 & 171.7 & 11.4 & & 193. 7 \\
\hline 12 & $2-12-4$ & 11. $11-65.67-22.22$ & 270.3 & 140.3 & & & 31.5 & 193. 7 \\
\hline 13 & $2-12-6$ & $10-$ & 182. 9 & 243.7 & 76.7 & & & \\
\hline 13 & $2-12-6$ & $10-$ & 056 & 27. 2 & 237.4 & & & 225. \\
\hline $\begin{array}{l}13 \\
13\end{array}$ & $\begin{array}{l}2-12-6 \\
2-12-6\end{array}$ & $\begin{array}{l}10- \\
10-\end{array}$ & $\begin{array}{r}95.6 \\
270.3\end{array}$ & $\begin{array}{l}346.9 \\
140.3\end{array}$ & & 25.9 & 71.5 & \\
\hline 14 & $2-14-2$ & $11.11-77.78$ & 270.3 & 115.7 & & & & 52. \\
\hline 14 & & $11-77.78$ & 172.3 & & 85.9 & & & 173. 7 \\
\hline 15 & $2-16-2$ & 10 & 270.3 & 115.7 & & & & 92. \\
\hline $\begin{array}{l}15 \\
16\end{array}$ & $\begin{array}{r}2-16-2 \\
2.43-12-2\end{array}$ & 10 & & & 85. 9 & & & 213.7 \\
\hline $\begin{array}{l}16 \\
16\end{array}$ & $\begin{array}{l}2.43-12-2 \\
2.43-12-2\end{array}$ & $\begin{array}{l}14.7 \\
14.7\end{array}$ & $\begin{array}{l}309.7 \\
291.1\end{array}$ & $\begin{array}{r}93.6 \\
115.6\end{array}$ & 16.4 & 5.5 & & \\
\hline 16 & $2-2$ & 14.7 & 328.4 & 71.5 & & & 15.3 & \\
\hline 16 & 2. 43-12-2 & 14. 7 & 230.4 & & 85.9 & & & 97.8 \\
\hline 17 & $3-8-3$ & 21.4 & 259.0 & $170^{\circ}$ & 128.6 & & & \\
\hline 17 & & 21.4 & 112.6 & 173.5 & & 43.4 & & \\
\hline 17 & 3 & 21.4 & 258.9 & .... & 128.8 & & & \\
\hline $\begin{array}{l}17 \\
18\end{array}$ & $\begin{array}{l}3-8-3 \\
3-8-5\end{array}$ & $\begin{array}{r}21 .+42-57.14- \\
18.75-50-\end{array}$ & $\begin{array}{l}259.3 \\
210.1\end{array}$ & 58 & $\begin{array}{l}128.8 \\
171.5\end{array}$ & & & \\
\hline 18 & & 25 & & 289.1 & & 57.8 & & \\
\hline 18 & $3-8-5$ & 25 & 259.2 & & 128. 2 & & 40.3 & \\
\hline 18 & $\begin{array}{l}3-8-5 \\
3-8-6\end{array}$ & 18. 75-5 & 160.8 & 870 & 214. 7 & & & 60.8 \\
\hline $\begin{array}{l}19 \\
19\end{array}$ & $\begin{array}{l}3-8-6 \\
3-8-6\end{array}$ & $\begin{array}{l}17.65- \\
17.65-\end{array}$ & $\begin{array}{l}185.7 \\
112.2\end{array}$ & 87.0 & $\begin{array}{l}193.0 \\
257.6\end{array}$ & & & 90.8 \\
\hline 19 & 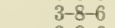 & & 259.3 & & 128.2 & & 60.3 & \\
\hline 19 & $3-8-6$ & 5. 29 & & & & 55.0 & & \\
\hline 20 & $3-8-8$ & 2. $11-42.11$ & 136.8 & 144.8 & - 236.0 & & & \\
\hline 20 & & 15. & & & 343. & & & 151. 2 \\
\hline 20 & & & & & 115.7 & 40.5 & 100.0 & \\
\hline 21 & $3-10-$ & 8. $82-23.53$ & 267.0 & D1. & 121.6 & & & \\
\hline
\end{tabular}


TABLE 7.-Weights of materials which may be used in making a ton of standard fertilizers-Continued

\begin{tabular}{|c|c|c|c|c|c|c|c|c|}
\hline \multirow{2}{*}{$\begin{array}{l}\text { Num- } \\
\text { ber }\end{array}$} & \multirow{2}{*}{$\begin{array}{l}\text { Analysis } \\
\text { formula }\end{array}$} & \multirow{2}{*}{ Ratio } & \multirow{2}{*}{$\mathrm{NH}_{4} \mathrm{H}_{2} \mathrm{PO}_{4}$} & \multirow{2}{*}{$\mathrm{KH}_{2} \mathrm{PO}_{4}$} & \multirow{2}{*}{$\mathrm{KNO}_{3}$} & \multicolumn{3}{|c|}{$\begin{array}{l}\text { Fertilizer constituents sup- } \\
\text { plied by other materials }\end{array}$} \\
\hline & & & & & & $\mathrm{NH}_{3}$ & $\mathrm{~K}_{2} \mathrm{O}$ & $\mathrm{P}_{2} \mathrm{O}_{5}$ \\
\hline 21 & $3-10-4$ & 17. $65-58.82-23.53$ & 128.5 & $\begin{array}{l}\text { Pounds } \\
231.3\end{array}$ & Pounds & $\begin{array}{r}\text { Pounds } \\
41.0\end{array}$ & Pounds & Pounds \\
\hline 21 & $3-10-4$ & $17.65-58.82-23.53$ & 210.1 & & 171.7 & & & 70.4 \\
\hline 21 & $3-10-4$ & $17.65-58.82-23.53$ & 324.1 & & 71.8 & & 46.6 & ........... \\
\hline 22 & $3-10-6$ & 15. $79-52.63-31.58$ & 218.1 & 125.3 & 164.6 & & (............... & $\ldots$ \\
\hline 22 & $3-10-6$ & 15. 79-52. $63-31.58$ & 30.8 & 346.9 & & 55.4 & |-nent & |. \\
\hline 22 & $3-10-6$ & $15.79-52.63-31.58$ & 112. 2 & _....... & 257.6 & & & 130.8 \\
\hline 22 & $3-10-6$ & 15. 79-52. $63-31.58$ & 324.0 & $-\bar{n}$ & 71.2 & & 86.8 & (1............ \\
\hline 23 & $3-12-3$ & $16.67-66.67-16.66$ & 323.8 & 76.9 & 71.7 & & 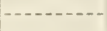 & 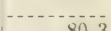 \\
\hline 23 & $3-12-3$ & $16.67-66.67-16.66$ & 258.8 & 173.5 & 128.8 & & & 80.3 \\
\hline 23 & $3-12-3$ & 16. $67-66.67-16.66$ & 242. 2 & 173.5 & 14.2 & 4. 2 & 53.4 & - \\
\hline 23 & $3-12-3$ & 16. $67-66.67-16.66$ & $\begin{array}{l}388.9 \\
299.3\end{array}$ & 105.9 & $\begin{array}{l}14.2 \\
93.1\end{array}$ & & 53.4 & (n. \\
\hline 24 & $3-12-4$ & 15. $79-63.16-21.05$ & $\begin{array}{l}299.3 \\
193.3\end{array}$ & $\begin{array}{l}105.9 \\
231.3\end{array}$ & 93.1 & 31.4 & & $\ldots$ \\
\hline 24 & $3-12-4$ & 15. 79-63.16-21.05 & $\begin{array}{l}193.3 \\
210.1\end{array}$ & & 171.7 & 31.4 & & 111) 4 \\
\hline $\begin{array}{l}24 \\
24\end{array}$ & $\begin{array}{l}3-12-4 \\
3-12-4\end{array}$ & & $\begin{array}{l}210.1 \\
388.9\end{array}$ & & 14. 2 & & 73.4 & 111). 4 \\
\hline $\begin{array}{l}24 \\
25\end{array}$ & $\begin{array}{r}3-12-4 \\
3.64-12-0\end{array}$ & $\begin{array}{r}15.79-63.16-21.05 \\
23.27-76.73-0\end{array}$ & $\begin{array}{l}388.9 \\
388.9\end{array}$ & & & 15.3 & & (n.............. \\
\hline $\begin{array}{l}25 \\
26\end{array}$ & $\begin{array}{l}3.64-12-0 \\
3.64-12-3\end{array}$ & & 367.0 & 25.8 & 109.7 & & & n. \\
\hline $\begin{array}{l}26 \\
26\end{array}$ & 3. $64-12-3$ & $19.53-64.38-16.09$ & 242.2 & 173.5 & & 37.0 & & $-\ldots+2$ \\
\hline 26 & 3. $64-12-3$ & $19.53-64.38-16.09$ & 345.3 & & 128.8 & & & 23.9 \\
\hline 26 & 3. $64-12-3$ & $19.53-64.38-16.09$ & 388.9 & & 90.2 & & 18.0 & .... \\
\hline 27 & $4-8-4$ & $25-50-25$ & 63.7 & 231.3 & & 70.6 & $\ldots$ & $x_{0}$ \\
\hline 27 & $4-8-4$ & $25-50-25$ & 259.3 & & 171.7 & 12.7 & $\ldots$ & ..... \\
\hline 28 & $4-8-6$ & $22.22-44.45-33.33$ & 253.2 & 7.1 & 252.3 & - & & \\
\hline 28 & $4-8-6$ & $22.22-44.45-33.33$ & $247 . \overline{3}$ & & 257.6 & & & T. 4 \\
\hline 28 & $4-8-6$ & 22. $22-44.45-33.33$ & 259. 2 . & & 246.9 & & 5.0 & (.......... \\
\hline 28 & $4-8-6$ & $22.22-44.45-33.33$ & & 306.6 & 29.8 & 75.0 & -- & - \\
\hline 29 & $4-8-10$ & $18.18-36.37-45.45$ & 155.5 & 122.7 & 338.3 & & & \\
\hline 29 & $4-8-10$ & $18.18-36.37-45.45$ & 51.4 & (2) & 429. 4 & & & 125.3 \\
\hline 29 & $4-8-10$ & $18.18-36.37-45.45$ & 259.2 & & 246.9 & & 85.0 & ............ \\
\hline 29 & $4-8-10$ & 18. $18-36.37-45.45$ & $-1--$ & 306.6 & 201.6 & 46. 0 & $-\cdots$ & (......... \\
\hline 30 & $4-10-2$ & 25-62.5-12.5 & 226.3 & 115.6 & & 46. 6 & -.. & $\ldots$ \\
\hline 30 & $4-10-2$ & $25-62.5-12.5$ & 324.0 & 313 & 85.9 & 17.5 & $-\cdots$ & 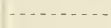 \\
\hline 31 & $4-10-4$ & $22.22-55.56-22.22$ & 128.5 & 31.3 & 1717 & 61.0 & $-\cdots$ & 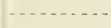 \\
\hline 31 & $4-10-4$ & $22.22-55.56-22.22$ & 324.0 & & 171.7 & 3.1 & $\cdots$ & .... \\
\hline $\begin{array}{l}32 \\
33\end{array}$ & $\begin{array}{l}4-12-0 \\
4-12-4\end{array}$ & $\begin{array}{r}25-75-0 \\
20-60-20\end{array}$ & $\begin{array}{l}388.9 \\
366.9\end{array}$ & 26.0 & 152.4 & 22.5 & & - \\
\hline 33 & $4-12-4$ & $20-60-20$ & 193. 3 & 231.3 & & & 51.4 & \\
\hline 33 & $4-12-4$ & $20-60-20$ & 345.3 & & 171. 7 & & & 26.9 \\
\hline 33 & $4-12-4$ & $20-60-20$ & 388.9 & & 132.9 & & 18. 1 & $\ldots$ \\
\hline 34 & 4. $86-8-4$ & $28.83-47.45-23.72$ & 63.7 & 231.3 & & 87.8 & - n....... & 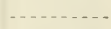 \\
\hline 34 & 4. $86-8-4$ & $28.83-47.45-23.72$ & 259.3 & & 171.7 & 29.9 & ans & ........ \\
\hline 35 & 4. $86-8-6$ & $25.77-42.42-31.81$ & 259.2 & & 257.6 & 15. 4 & -. & $\ldots \ldots$ \\
\hline 35 & 4. $86-8-6$ & $25.77-42.42-31.81$ & & 306.6 & 29.8 & 92.2 & $\ldots$ & $\ldots . .$. \\
\hline 36 & 4. $86-10-0$ & 32. $71-67.29-0$ & 324.0 & & & 49.3 & - & ……. \\
\hline 37 & 4. $86-10-2$ & $28.83-59.31-11.86$ & 226.3 & 115.6 & & 63.8 & $-\cdots$ & ............ \\
\hline 37 & 4. $86-10-2$ & $28.83-59.31-11.86$ & 324.0 & & 85.9 & 34.8 & - & (.......... \\
\hline 38 & $4.86-10-4$ & 25. $77-53.02-21.21$ & 128.5 & 231. 3 & $771-7$ & 78.2 & $\ldots$ & $\cdots$ \\
\hline 38 & 4. $86-10-4$ & 25. $77-53.02-21.21$ & 324.0 & 2918 & 171.7 & 20.4 & $-\cdots$ & $\ldots . .$. \\
\hline 39 & 4. $86-12-4$ & $23.30-57.52-19.18$ & 193.3 & 231.3 & 1717 & 68.6 & -.. &.- \\
\hline 39 & 4. $86-12-4$ & $23.30-57.52-19.18$ & 388.9 & 1533 & 171.7 & 10. 7 & 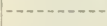 & n.............. \\
\hline 40 & $5-4-5$ & $35.71-28.57-35.72$ & - & 153,3 & $\begin{array}{l}100.9 \\
914.7\end{array}$ & 83.0 & $\cdots$ & $\ldots \ldots$ \\
\hline 40 & $\begin{array}{l}5-4-5 \\
5-7-5\end{array}$ & $35.71-28.57-35.72$ & 129.6 & & 214.7 & $\begin{array}{l}44.6 \\
30.2\end{array}$ & $-\ldots$ & . . n \\
\hline 41 & $\begin{array}{l}5-7-5 \\
5-7-5\end{array}$ & $29.41-41.18-29.41$ & 226.8 & 2683 & 214.7 & 30.2 & $\cdots$ & ... \\
\hline $\begin{array}{l}41 \\
42\end{array}$ & $\begin{array}{l}5-7-5 \\
5-8-3\end{array}$ & $29.41-41.18-29.41$ & 112.6 & $\begin{array}{l}268.3 \\
173.5\end{array}$ & 15. & $\begin{array}{l}97.4 \\
83.3\end{array}$ & $-\cdots$ & - \\
\hline $\begin{array}{l}42 \\
42\end{array}$ & $\begin{array}{l}5-8-3 \\
5-8-3\end{array}$ & $\begin{array}{l}31.25-50-18.75 \\
31.25-50-18.75\end{array}$ & 259.3 & & 128.8 & 39.9 & & \\
\hline 43 & $5-8-5$ & $27.78-44.44-27.78$ & 14.9 & 289.1 & & 97.8 & & $-\ldots \ldots \ldots$ \\
\hline 43 & $5-8-5$ & $27.78-44.44-27.78$ & 259.2 & & 214.7 & 25.4 & & .......... \\
\hline 44 & $5-8-7$ & $25-40-35$ & & 306.6 & 73.0 & 87.7 & & $\ldots$. \\
\hline 44 & $5-8-7$ & $25-40-35$ & 259.3 & & 300.6 & 10.9 & $-2-0$ & $\ldots . . . .$. \\
\hline 45 & $5-10-3$ & $27.78-55.55-16.67$ & 177.4 & 173.5 & & 73.7 & $\ldots$ & $\ldots \ldots$ \\
\hline 45 & $5-10-3$ & $27.78-55.55-16.67$ & 324.0 & & 128.8 & 30.3 & $\ldots$ & $\ldots \ldots \ldots$ \\
\hline 46 & $5-10-5$ & $25-50-25$ & .79 .7 & 289.1 & & 88.2 & $\ldots . .$. & $\ldots \ldots \ldots$ \\
\hline 46 & $5-10-5$ & $25-50-25$ & 324.0 & & 214.6 & 15.9 & $\ldots$ & $\ldots$ \\
\hline 47 & $6-8-4$ & $33.33-44.45-22.22$ & 63.8 & 1.3 & & 110.6 & $\cdots$ & (........... \\
\hline 47 & $6-8-4$ & $33.33-44.45-22.22$ & 259.2 & & 171.7 & 52.7 & -- & ... \\
\hline 48 & $6.07-7-5$ & $33.59-38.74-27.67$ & 226.8 & & 214.7 & 51.6 & -- & .... \\
\hline 48 & $6.07-7-5$ & $33.59-38.74-27.67$ & (n) & 3 & $\begin{array}{l}15.5 \\
44.0\end{array}$ & 118. 8 & $-\cdots$ & .... \\
\hline 49 & $7-6-5$ & $38.89-33.33-27.78$ & 1044 & .0 & 214.7 & $\begin{array}{r}132.6 \\
75.0\end{array}$ & - & $\ldots$ \\
\hline $\begin{array}{l}49 \\
50\end{array}$ & $\begin{array}{r}7-6-5 \\
8-8-0\end{array}$ & $38.89-33.33-27.78$ & $\begin{array}{l}194.4 \\
259.2\end{array}$ & & & $\begin{array}{r}75.0 \\
131.6\end{array}$ & & $\ldots$ \\
\hline $\begin{array}{l}50 \\
51\end{array}$ & 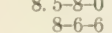 & $\begin{array}{r}51.52-48.48-0 \\
40-30-30\end{array}$ & & 230.0 & 86.9 & 145.4 & & ... \\
\hline 51. & $8-6-6$ & $40-30-30$ & 194.4 & & 257.6 & 87.8 & & ......... \\
\hline 52 & $10-5-0$ & $66.67-33.33-0$ & 162.0 & & & 176.1 & & - \\
\hline
\end{tabular}


If it is desired to combine a fourth material in a mixture with three others containing two fertilizing elements each, such as monoammonium phosphate, monopotassium phosphate, and potassium nitrate, two special cases may be considered, depending on whether the fourth material contains one, or two, fertilizer constituents.

A nitrogen compound such as ammonium nitrate is represented in the triangle of Plate IV by the point $A$. By plotting the points $D, E$, and $F$ as before to represent the ammonium and potassium phosphates and potassium nitrate, the area $A D E F$ will inclose all possible fertilizer ratios that can be prepared from mixtures of these materials.

If the fourth material has a composition similar to tankage (containing 8.5 per cent of $\mathrm{NH}_{3}$, and 5 per cent of $\mathrm{P}_{2} \mathrm{O}_{5}$ ), it may be represented in the figure by the point $P$, and only fertilizer ratios falling within the area $P D E F$ can be made from these four materials.

In calculating the quantities of the four materials required for a ton of any given analysis formula, such as the 8-6-6 mixture represented at the point $L$, the two $\mathrm{NH}_{3}-\mathrm{P}_{2} \mathrm{O}_{5}$ materials may be taken arbitrarily in any proportion such that the point $Q$ representing the mixture will form the apex of a trianghe on the base $E F$ inclosing $L$. It is apparent from the figure that the location of the point $Q$ may vary from $P$ (representing the tankage alone) to the point $Q^{\prime}$, which becomes the apex of the triangle when the side $F Q^{\prime}$ passes through $L$. The relative quantities of the two materials required to form a mixture containing a given ratio $(r)$ of $\mathrm{NH}_{3}: \mathrm{P}_{2} \mathrm{O}_{5}$ corresponding to $Q$ is determined as follows:

Let $x=$ quantity of the first material.

$y=$ quantity of the second material.

$a=$ percentage of $\mathrm{NH}_{3}$ in first material.

$a^{\prime \prime}=$ percentage of $\mathrm{NH}_{3}$ in second material.

$b=$ percentage of $\mathrm{P}_{2} \mathrm{O}_{5}$ in first material.

$b^{\prime \prime}=$ percentage of $\mathrm{P}_{2} \mathrm{O}_{5}$ in second material .

$$
\begin{gathered}
\text { Then, } \frac{a x+a^{\prime \prime} y}{b x+b^{\prime \prime} y}=r \\
\text { or } \\
y=\frac{a-r b}{r b^{\prime \prime}-a^{\prime \prime}} x
\end{gathered}
$$

For monoammonium phosphate and tankage,

$$
a=14.8 ; a^{\prime \prime}=8.5 ; b=61.72 ; \text { and } b^{\prime \prime}=5
$$

For monoammonium phosphate and ammonium nitrate,

$$
a=14.8 ; a^{\prime \prime}=42.55 ; b=61.72 ; \text { and } b^{\prime \prime}=0
$$

If a ratio of $\mathrm{NH}_{3}: \mathrm{P}_{2} \mathrm{O}_{5}$ in the mixture is selected corresponding to the point $Q$, which represents 55 parts of $\mathrm{NH}_{3}$ to 45 of $\mathrm{P}_{2} \mathrm{O}_{5}, r=55 / 45$ : whence for tankage with monoammonium phosphate, $y=25.4 x$, and for ammonium nitrate with monoammonium phosphate, $y=1.43 x$.

Mixtures corresponding to the point $Q$ may therefore be prepared from 25.4 pounds of tankage, or 1.43 pounds of ammonium nitrate, with one of monoammonium phosphate. 
The quantities of these materials, together with monopotassium phosphate and potassium nitrate, required for a ton of an 8-6-6 fertilizer may then be calculated by help of equations (1), (2), and (3), with results as follows:

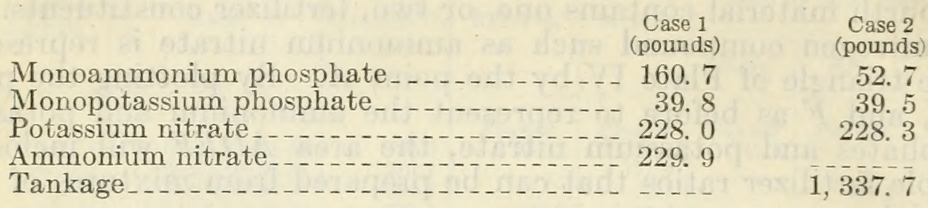

In a similar way, calculations may be made of fertilizer mixtures using four materials of other composition, or any additional number of fertilizer compounds.

\section{SUMMARY}

The materials now used in the fertilizer industry contain, as a rule, only one of the three plant-food constituents. Consequently, the calculation of the quantities of these materials required for a mixed fertilizer of given analysis formula is a comparatively easy arithmetical process.

As the number of materials, particularly of single constituent materials, available for a fertilizer mixture is reduced, the range of fertilizer analysis formulae which they are capable of making is also reduced, and the difficulty of the ordinary arithmetical method of calculating any mixture may be greatly increased.

It is pointed out that the number of materials used in mixed fertilizers is likely to decrease, and that the concentration of those used will probably increase.

A method is presented whereby it can be quickly ascertained, by means of triangular diagrams, whether a mixed fertilizer of given analysis formula can be made from combinations of two-fertilizerconstituent materials.

Formulae are given for the computation of the respective quantities of these materials required for making mixed fertilizers in those cases in which the fertilizer can be made from these materials.

Tables are presented giving the results of such computations for the 52 analysis formulae adopted by conferences of agronomists and fertilizer manufacturers as standard for the 24 States represented.

\footnotetext{
ADDITIONAL COPIES

OF THIS PUBLICATION MAY BE PROCURED FROM THE SUPERINTENDENT OF DOCUMENTS

GOVERNMENT PRINTING OFFICE

WASHINGTON, D. C. $\Delta T$

5 CENTS PER COPY
} 
